JURMAK

Vol. 02, No. 01, November 2015

\title{
ANALISIS PENGARUH CURRENT RATIO (CR), DEBT TO EQUITY RATIO (DER), DAN NET PROFIT MARGIN (NPM) TERHADAP DIVIDEND PAYOUT RATIO (DPR) PADA PERUSAHAAN MANUFAKTUR YANG TERDAFTAR DI BURSA EFEK INDONESIA PERIODE 2010-2014
}

\author{
Lidya Martha \\ Indra \\ Dosen STIE “KBP” Padang \\ Email : lidyam83@gmail.com
}

\begin{abstract}
ABSTRAK
Devidend adalah bagian dari laba yang diberikan kepada para pemegang saham. Besar kecilnya dividend yang dibayarkan oleh perusahaan kepada pemegang saham tergantung pada kebijakan dividend masing-masing perusahaan. Penelitian ini bertujuan untuk mengetahui seberapa besar faktor-faktor current ratio, debt to equity ratio dan net profit margin berpengaruh terhadap Dividend Payout Ratio. Populasi dalam penelitian ini adalah perusahaan manufaktur yang terdaftar di Bursa Efek Indonesia (BEI) periode tahun 2010-2014 yang berjumlah 15 perusahaan. Dimana setiap perusahaan yang diambil adalah perusahaan yang memiliki data lengkap meliputi CR, DER, dan NPM serta membagikan dividen berturutturut selama periode 2010-2014. Adapun sampel penelitian ini diambil dengan menggunakan teknik purposive sampling yaitu pemilihan anggota sampel berdasarkan kriterian-kriteria tertentu. Alat analisis yang digunakan dalam penelitian ini adalah regresi linear berganda. Berdasarkan penelitian ini, secara parsial ada satu variabel yaitu net profit margin yang berpengaruh signifikan positif dan variabel current ratio tidak berpengaruh positif dan tidak signifikan, sedangkan debt to equity ratio berpengaruh positif namun tidak signifikan terhadap Devidend Payout Ratio. Secara simultan variabel ROA, CR, DER dan Size berpengaruh signifikan terhadap Devidend Payout Ratio. Hal ini dibuktikan dengan nilai sig-F lebih kecil dari signifikansi 5\% yaitu sebesar 0,035.
\end{abstract}

Kata Kunci: Dividend Payout Ratio (DPR), Current Ratio (CR), Debt to Equity Ratio (DER), Net Profit Margin (NPM).

\section{PENDAHULUAN}

Aktivitas investasi merupakan aktivitas yang dihadapkan pada berbagai macam risiko dan ketidakpastian yang sering kali sulit diprediksikan oleh para investor. Untuk mengurangi kemungkinan risiko dan ketidakpastian yang akan terjadi, investor memerlukan berbagai macam informasi, baik informasi yang diperoleh dari kinerja perusahaan maupun informasi lain yang relevan seperti kondisi ekonomi dan politik dalam suatu negara. Informasi yang diperoleh dari perusahaan lazimnya didasarkan pada kinerja perusahaan yang tercermin dalam laporan keuangan (Laksono, 2006).

Perusahaan harus menentukan kebijakan yang tepat untuk menangani masalah yang terkait dengan dividen. Masing-masing perusahaan menetapkan kebijakan dividen yang berbeda-beda. Perusahaan perlu membuat kebijakan tentang besarnya laba yang akan 
dibagikan kepada pemegang saham atau biasa disebut Dividend Payout Ratio (DPR), dan besarnya laba yang akan ditahan oleh perusahaan. Semakin besar laba yang dibagikan dalam bentuk dividen akan semakin menarik bagi calon investor. Ini karena para calon investor menilai bahwa perusahaan dalam kondisi yang sehat dan memiliki prospek yang baik di masa mendatang.

Kebijakan dividen perusahaan tergambar pada dividend payout rationya yaitu persentase laba yang dibagikan dalam bentuk dividen tunai, artinya besar kecilnya dividend payout ratio akan mempengaruhi keputusan investasi para pemegang saham dan disisi lain berpengaruh pada kondisi keuangan perusahaan. Pertimbangan mengenai dividend payout ratio ini diduga sangat berkaitan dengan kinerja keuangan perusahaan. Bila kinerja keuangan perusahaan bagus maka perusahaan tersebut akan mampu menetapkan besarnya dividend payout ratio sesuai dengan harapan pemegang saham dan tentu saja tanpa mengabaikan kepentingan perusahaan untuk tetap sehat dan tumbuh.

Perusahaan yang terdaftar di BEI tidak semuanya membagikan dividen kepada para pemegang sahamnya, baik itu dalam bentuk dividen tunai maupun dividen saham. Hal tersebut disebabkan oleh adanya pertimbangan-pertimbangan yang berbeda dalam membuat keputusan/kebijakan dan pembayaran dividen dalam setiap perusahaan. Sektor manufaktur merupakan sektor yang paling banyak membagikan dividen kepada para pemegang sahamnya selama kurun periode 2010-2014 dibandingkan sektor lain yang terdaftar di Bursa Efek Indonesia (BEI).

Penelitian ini menggunakan variabel penelitian, diantaranya yaitu: dividend payout ratio sebagai variabel dependen, dan current ratio, debt to equity ratio, net profit margin sebagai variabel independen. Berdasarkan masalah tersebut di atas berkaitan dengan faktor-faktor yang mempengaruhi dividend payout ratio, maka penelitian ini mengambil judul "Analisis Pengaruh Current Ratio (CR), Debt to Equity Ratio (DER), dan Net Profit Margin (NPM) Terhadap Dividend Payout Ratio (DPR) Pada Perusahaan Manufaktur yang Terdaftar Di Bursa Efek Indonesia periode 2010-2014”.

\section{LANDASAN TEORI}

Rasio keuangan akan memberi cara bagi analis untuk membuat perbandingan yang berarti dari data keuangan perusahaan melalui:

1. waktu yang berbeda, artinya membandingkan rasio-rasio perusahaan yang sama dari laporan keuangan terdahulu,

2. perusahaan lain yang berbeda, yang mempunyai skala dan lingkungan yang kurang lebih sama.

Ada beberapa jenis rasio yang dapat digunakan untuk mengukur kinerja keuangan sebuah perusahaan, yaitu (Harahap (2004):

1. Kemampuan laba (Profitability Ratio)

Rasio profitabilitas menggambarkan kemampuan perusahaan dalam menghasilkan laba secara relatif. Relatif disini artinya laba tidak diukur dari besarnya secara mutlak tetapi diperbandingkan dengan unsur-unsur atau tolak ukur lainnya. Tolak ukur yang dipakai biasanya Pendapatan, Dana dan Modal. Beberapa jenis rasio profitabilitas ini dapat dikemukakan sebagai berikut: 
1) Rasio Laba atas Penjualan (Net Profit Margin),

2) Rasio Laba Sebelum Bunga dan Pajak atas Penjualan

3) Rasio Laba Kotor atas Penjualan (Gross Profit Margin),

4) Rasio Laba Operasi atas Total Investasi (Return on Investment),

5) Rasio Laba atas Modal (Return on Equity).

2. Rasio Likuiditas (Liquidity Ratio)

Rasio likuiditas menggambarkan kemampuan perusahaan untuk menyelesaikan kewajiban jangka pendeknya. Rasio-rasio ini dapat dihitung melalui sumber informasi tentang modal kerja yaitu pos-pos aktiva lancar dan utang lancar. Beberapa rasio likuiditas ini adalah sebagai berikut:

1) Rasio Lancar (Current Ratio),

2) Rasio Cair (Quick Ratio/Acid Test Ratio)

3) Rasio kas (Cash Ratio).

3. Rasio Aktivitas (Activity Ratio)

Rasio ini menggambarkan kinerja perusahaan dalam pengelolaan persediaan dan piutangnya, rasio ini dapat dibagi menjadi 4 (empat), yaitu:

1) Rasio Perputaran Persediaan (Inventory Turn Over),

2) Rasio Hari Persediaan (Inventory Period),

3) Rasio Perputaran Piutang (Account Receivable Turn Over),

4) Rasio Periode Pengumpulan Piutang (Average Collection Period).

4. Rasio Efektivitas Penggunaan Dana dan Biaya

Rasio ini untuk melihat sampai seberapa jauh efisiensi dan efektivitas penggunaan dana dan biaya. Biasanya biaya tersebut diperbandingkan dengan hasil penjualan. Rasio ini dibagi menjadi 5, yaitu:
1) Rasio Harga Pokok Penjualan atas Penjualan,

2) Rasio Harga Pokok Penjualan dan Beban Operasi atas Penjualan,

3) Rasio Beban Penjualan atas Penjualan,

4) Rasio Beban Administrasi,

5) Rasio Beban Keuangan.

5. Rasio Solvabilitas (Solvability Ratio) Rasio solvabilitas menggambarkan kemampuan perusahaan dalam memenuhi kewajiban jangka panjangnya atau kewajibankewajibannya apabila perusahaan dilikuidasi. Rasio ini dapat dihitung dari pos-pos yang sifatnya jangka panjang seperti aktiva tetap dan utang jangka panjang. Rasio solvabilitas antara lain:

1) Rasio Kewajiban Jangka Panjang atas Harta/Aktiva (Debt To Asset Ratio),

2) Rasio Kewajiban Jangka Panjang atas Modal (Debt To Equity Ratio)

3) Rasio Kewajiban Jangka Panjang atas Kapitalisasi.

Manajemen memiliki 2 (dua) alternatif dalam perlakuannya terhadap penghasilan/laba bersih sesudah pajak (EAT) perusahaan, yaitu yang pertama dibagi kepada para pemegang saham perusahaan dalam bentuk dividen dan yang kedua diinvestasikan kembali kepada perusahaan sebagai laba ditahan (retained earning). Pada umumnya sebagai EAT (Earning After Tax) dibagi dalam bentuk dividen dan sebagian lagi diinvestasikan kembali, artinya manajemen harus membuat keputusan tentang besarnya EAT yang dibagikan sebagai dividen (Atmadja, 2003).

Kebijakan dividen (dividend policy) merupakan keputusan yang berkaitan dengan penentuan apakah keuntungan/laba perusahaan akan dibagikan kepada pemegang saham 
sebagai dividen atau akan ditahan sebagai laba ditahan dan selanjutnya untuk diinvestasikan kembali dimasa yang akan datang (Suhartono, 2004). Laba yang disimpan kembali atau laba ditahan merupakan salah satu sumber dana terpenting dalam membiayai pertumbuhan perusahaan, tetapi dividen membentuk arus uang yang semakin mengalir ke tangan pemegang saham.

\section{METODE PENELITIAN}

Pendekatan yang digunakan dalam penelitian ini adalah deskriptif kuantitatif, Berdasarkan tingkat eksplanasinya bersifat deskriptif dan apabila dilihat dari jenis datanya tergolong penelitian kuantitatif. Penelitian kuantitatif ini menekankan pada pengujian teori-teori melalui pengukuran variabel-variabel penelitian dengan angka dan melakukan analisis data dengan prosedur statistik.

Penelitian ini dilakukan melalui internet di Bursa Efek Indonesia (IDX) dengan situs www.idx.co.id.yaitu dengan melihat laporan keuangan perusahaan yang tercatat di Bursa Efek Indonesia melalui web www.idx.co.id.

Jenis data yang dipergunakan dalam penelitian ini adalah data sekunder, yaitu sumber data penelitian yang diperoleh secara tidak langsung, yaitu melalui media perantara. Data sekunder umumnya merupakan data yang dipublikasikan maupun yang tidak dipublikasikan Data sekunder yang dibutuhkan berasal dari Indonesian capital Market Direktory (ICMD) edisi 2010, 2011, 2012, 2013, 2014.

Populasi dari penelitian ini adalah semua perusahaan manufaktur yang terdaftar (go public) dan menerbitkan laporan keuangan tahunan yang telah diaudit dan dipublikasikan di Bursa Efek Indonesia (BEI) untuk periode tahun 2010 hingga 2014.Jumlah populasi pada penelitian ini adalah 136 perusahaan.

Sampel penelitian merupakan sebagian atau wakil dari populasi yang diteliti. Syarat sampel adalah bahwa sampel representatif bagi keseluruhan populasi. Apa yang ditemukan dalam penelitian sampel juga dianggap berlaku bagi populasi. Dalam penelitian ini populasi yang ada tidak digunakan seluruhnya sebagai sampel. Metode pengambilan sampel yang digunakan dalam penelitian ini adalah purposive sampling. Kriteria yang dijadikan sampel dalam penelitian ini adalah:

1. Perusahaan manufaktur yang listed di BEI yang selalu menyajikan laporan keuangan tahun buku berakhir 31 Desember selama periode pengamatan (2010-2014).

2. Perusahaan harus sudah listing pada awal periode pengamatan dan tidak di delisting sampai akhir periode pengamatan.

3. Perusahaan tersebut selalu membagikan deviden selama lima tahun berturut-turut pada tahun 2010-2014.

4. Pada awal periode pengamatan hingga akhir periode pengamatan menghasilkan laba yang positif.

5. Perusahaan yang dijadikan sampel memiliki kelengkapan data (laporan keuangan) yang berkaitan dengan data sesuai dengan model yang digunakan dalam penelitian ini.

Jumlah sampel yang memenuhi kriteria dalam penelitian ini adalah sejumlah 15 perusahaan.

Data yang dikumpulkan dalam penelitian ini adalah data sekunder sehingga metode pengumpulan data menggunakan cara non participant observation. Data yang berupa variable Dividend Payout ratio (DPR) diperoleh 
dengan cara diambil langsung dari ICMD (Indonesian Capital market Directory) selama 5 tahun berturut-turut yaitu dari tahun 2010-2014. Berdasarkan kriteria-kriteria tersebut dapat diperoleh sampel sebanyak 10 perusahaan.

Dividend Payout Ratio
merupakan Laba bersih setelah pajak yang ditetapkan untuk membayar kepada para pemegang saham atau rasio yang mengukur pendapatan bersih yang dibayarkan dalam bentuk dividen. Dividend Payout Ratio didefinisikan sebagai rasio antara dividend per share (DPS) terhadap earning per share (EPS). Menurut Brigham (2001), Dividend Payout Ratio dapat dicari dengan menggunakan rumus sebagai berikut:

$$
D P R=\frac{\text { Dividend Per Share }(D P S)}{\text { Earning Per Share }(E P S)}
$$

Current Ratio (CR) yaitu rasio yang digunakan untuk mengukur aktiva lancar perusahaan bisa dipakai untuk memenuhi kewajiban lancarnya. Rasio ini merupakan alat ukur dari rasio likuiditas. Likuiditas adalah kemampuan perusahaan memenuhi kewajiban keuangan jangka pendek. Makin kuat posisi likuiditas suatu perusahaan terhadap prospek kebutuhan dana diwaktu-waktu mendatang, makin tinggi divident payout rationya.

Menurut Sutrisno (2000), rumus Current Ratio (CR) adalah:

Current Ratio
$\frac{\text { Aktiva Lancar }}{\text { Hutang Lancar }}$

Adanya pengumuman yang menyatakan bahwa tingkat likuiditas (current ratio) suatu perusahaan tinggi akan memberikan gambaran atau sinyal kepada para investor bahwa perusahaan tersebut memiliki kemampuan untuk memenuhi kewajiban-kewajiban jangka pendek.

Dengan kemampuan tersebut, para investor akan tertarik untuk menanamkan modalnya yang bertujuan untuk memperoleh laba berupa dividen. Hal ini sesuai dengan teori yang telah dikemukakan sebelumnya bahwa jika tingkat likuiditas (current ratio) tinggi maka besarnya dividend payout rationya juga akan tinggi.

Menurut Riyanto (1997), salah satu rasio yang termasuk dalam rasio solvabilitas/leverage adalah Debt to Equity Ratio (DER). Rasio ini digunakan untuk mengetahui berapa bagian dari setiap modal sendiri yang dijadikan jaminan untuk keseluruhan hutang (modal asing) perusahaan atau untuk menilai banyaknya hutang yang digunakan perusahaan. Aturan struktur finansil konservatif memberikan batas imbangan yang harus dipertahankan oleh suatu perusahaan mengenai besarnya modal asing dan modal sendiri. Diasumsikan bahwa pembelanjaan yang sehat itu pertama-tama harus dibangun dari modal sendiri yaitu modal yang tahan risiko, maka aturan finansiil tersebut menetapkan bahwa besarnya modal asing dalam keadaan bagaimanapun tidak boleh melebihi besarnya modal sendiri. Koefisien hutang yaitu angka perbandingan antara jumlah modal asing dengan modal sendiri tidak boleh melebihi 1:1.

Jika perusahaan menggunakan modal yang berasal dari pinjaman maka akan menimbulkan beban tetap berupa bunga pinjaman. Namun jika perusahaan menggunakan modal yang berasal dari pemilik perusahaan (modal sendiri), maka perusahaan wajib memberikan balas jasa pada mereka dalam bentuk dividen. Jadi, semakin besar pembelanjaan perusahaan yang menggunakan modal dari para pemegang sahamnya maka semakin besar pula dividen yang harus dibagikan. Para kreditur umumnya senang bila rasio ini 
rendah. Semakin rendah rasio tersebut berarti semakin tinggi tingkat pembelanjaan perusahaan yang disediakan oleh para pemegang saham dan semakin besar tingkat perlindungan kreditur dari kehilangan uang yang diinvestasikan ke perusahaan tersebut.

Menurut Sawir (2005), rumus untuk menghitung debt to equity ratio yaitu:

Debt to Equity Ratio $=\frac{\text { Total Hutang }}{\text { Modal (Equity) }}$

Semakin kecil rasio ini semakin baik. Untuk keamanan pihak luar rasio terbaik jika jumlah modal lebih besar dari jumlah utang atau minimal sama. Jika dihubungkan dengan pembayaran dividen maka akan berlaku hubungan yang berlawanan (negatif), artinya semakin tinggi rasio ini maka akan semakin kecil pembayaran dividen dan sebaliknya. Penelitian Harahap (2004) di Bursa Efek Jakarta periode tahun 1999 hingga 2001 terhadap 28 perusahaan manufaktur menunjukkan bahwa salah satu faktor yang mampu menjelaskan DPR pada perusahaan manufaktur adalah Debt to Equity Ratio (DER).

Menurut Riyanto (1997) tingkat efisiensi dan efektivitas pengelolaan perusahaan dapat diketahui dengan membandingkan laba yang diperoleh dengan kekayaan atau modal yang menghasilkan laba tersebut, atau dengan kata lain menghitung rentabilitasnya. Menurut Sawir (2005) NPM adalah rasio yang membandingkan net income dengan penjualan bersih operasi (sales), dapat digambarkan dalam formula sebagai berikut:

Net Profit Margin $=\frac{\text { Net Income }}{\text { Sales }}$

Crutchley dan Hansen (1989)

dalam Suhartono (2004) menemukan bukti bahwa earning volatility berpengaruh positif terhadap kebijakan dividen. Volatilitas keuntungan berkaitan erat dengan rasio dividen. Apabila tingkat keuntungan perusahaan semakin stabil maka perusahaan dapat memprediksi keuntungan-keuntungan dimasa yang akan datang dengan ketepatan yang lebih tinggi. Dengan demikian perusahaan tersebut bisa mempertahankan pembayaran sebagian besar dari keuntungannya dalam bentuk dividen.

Deskripsi variabel atau yang lebih dikenal dengan analisa deskriptif merupakan prosedur pengolahan data dengan menggambarkan dan meringkas data secara lebih ilmiah dalm bentuk tabel atau grafik. Data-data yang disajikan meliputi frekuensi, proporsi, dan rasio, ukuran-ukuran kecenderungan pusat (rata-rata hitung, median, modus) maupun ukuran-ukuran variasi (simpangan baku, variansi, rentang, dan kuartil). (Nursalam, 2008)

\section{Uji Normalitas}

Menurut Ghozali (2005), Uji normalitas adalah untuk mengetahui apakah dalam model regresi, variabel pengganggu atau residual memiliki distribusi normal. Seperti diketahui bahwa uji-t dan uji-F mengasumsikan bahwa nilai residual mengikuti distribusi normal. Jika asumsi ini dilanggar maka uji statistik menjadi tidak valid untuk jumlah sampel kecil. Cara untuk melihat normalitas residual adalah melalui analisis grafik (Histogram dan Normal P-Plot) dan analisis statistik.

1. Analisis Grafik, yaitu dengan melihat grafik Histogram dan grafik Normal P-Plot yang membandingkan distribusi kumulatif dari distribusi normal. Dasar pengambilan keputusan :

a) Jika data menyebar disekitar garis diagonal dan mengikuti arah garis diagonal atau grafik histogramnya menunjukkan pola 
distribusi normal, maka model regresi memenuhi asumsi normalitas.

b) Jika data menyebar jauh dari diagonal dan garis miring atau tidak mengikuti arah garis diagonal atau grafik histogram tidak menunjukkan pola distribusi normal, maka model regresi tidak memenuhi asumsi normalitas.

2. Analisis Statistik, yaitu dengan melihatuji statistik Non-Parametrik Kolmogorov-Smirnov (K-S). Apabila hasil atau nilai KolmogorovSmirnov (K-S) dan nilai Asymp. Sig (2-tailed) atau probabilitasnya diatas 0,05 (tingkat probabilitas), maka data telah memenuhi asumsi normalitas.

\section{Uji Multikolinearitas}

Uji Multikolinearitas dilakukan untuk melihat apakah ada variabel yang saling berkorelasi pada variabel bebas. Jika terjadi korelasi maka terdapat masalah multikolinieritas sehingga model regresi tidak dapat digunakan. Menurut Ghozali (2005) pengujian ini dapat dilihat melalui 1) Nilai Tolerance dan 2) Nilai Varians Inflation Factor (VIF).

1. Nilai Tolerance, nilai out off yang umum dipakai untuk menunjukkan adanya multikolinieritas adalah nilai tolerance $<0,10$.

2. Nilai Varians Inflation Factor (VIF), apabila :

a) Nilai VIF $>10$ maka diduga mempunyai persoalan multikolinearitas

b) Nilai VIF $<10$ maka tidak terdapat multikolinearitas.

\section{Uji Heteroskedastisitas}

Ghozali (2005) menyatakan bahwa pengujian ini bertujuan untuk melihat apakah dalam sebuah model regresi terjadi ketidaksamaan varian dari residual dalam rangkaian suatu pengamatan ke pengamatan lain. Jika varian dari residual dalam rangkaian suatu pengamatan ke pengamatan lain tetap, maka disebut terjadi homokedastisitas. Tetapi jika variansnya berbeda disebut heterokedastisitas.

Cara mendeteksi atau menguji terjadi atau tidaknya heteroskedastisitas adalah dengan melihat scatter plot, analisis data sebagai berikut :

a) Jika ada pola tertentu seperti titik yang ada membentuk pola yang teratur, maka telah terjadi heteroskedastisitas.

b) Jika tidak ada pola yang jelas, titik menyebar di atas dan di bawah angka 0 (nol), maka tidak terjadi heteroskedastisitas.

\section{Uji Autokorelasi}

Menurut Ghozali (2005) uji autokorelasi bertujuan menguji apakah dalam model regresi linier ada korelasi antara kesalahan pengganggu pada periode $t$ dengan kesalahan pengganggu pada periode $\mathrm{t}-1$ (sebelumnya).Jika terjadi korelasi, maka dinamakan problema autokorelasi. Ghozali (2005) juga menyatakan bahwa autokorelasi muncul karena observasi yang muncul secara berurutan sepanjang waktu berkaitan satu sama lainnya.

Cara yang digunakan untuk mendeteksi ada atau tidaknya autokorelasi yaitu dengan melihat uji Durbin-Watson ( $D W$ test), hipotesis yang akan diuji :

$\mathrm{H}_{0}$ : tidak ada autokorelasi $(\mathrm{r}=0)$

$\mathrm{H}_{\mathrm{a}}$ : ada autokorelasi $(\mathrm{r} \neq 0)$

Pengambilan keputusan ada tidaknya autokorelasi : 
Tabel

Tabel Pengambilan Keputusan ada tidaknya Autokorelasi

\begin{tabular}{|l|l|l|}
\hline Hipotesis Nol & Keputusan & Jika \\
\hline Tidak ada autokorelasi positif & Tolak & $0<\mathrm{d}<\mathrm{dl}$ \\
\hline Tidak ada autokorelasi positif & No Decision & $\mathrm{dl} \leq \mathrm{d} \leq \mathrm{du}$ \\
\hline Tidak ada korelasi negatif & Tolak & $4-\mathrm{dl}<\mathrm{d}<4$ \\
\hline Tidak ada korelasi negatif & No Decision & $4-\mathrm{du} \leq \mathrm{d} \leq 4-\mathrm{dl}$ \\
\hline $\begin{array}{l}\text { Tidak ada autokorelasi, positif atau } \\
\text { negatif }\end{array}$ & Tidak ditolak & $\mathrm{du}<\mathrm{d}<4-\mathrm{du}$ \\
\hline
\end{tabular}

Keterangan :

$\mathrm{d}=$ Durbin Watson hitung

$\mathrm{dl}=$ Durbin Watson - Lower

$\mathrm{du}=$ Durbin Watson - Upper

Nilai d $d_{\text {hitung }}$ ini selanjutnya dibandingkan dengan nilai dtabel pada tingkat signifikan 5\%, jumlah sampel 31 $(\mathrm{N}=31)$ dan jumlah variabel bebas (independent variable) adalah $5(\mathrm{k}=5)$. Jika nilai $\mathrm{d}_{\text {hitung }}$ berada diantara interval nilai du dan 4 - du maka tidak terdapat autokrelasi, sebaliknya jika nilai dhitung berada diluar interval nilai du dan $4-$ du maka terdapat penyimpangan dari asumsi ini.

Analisis Regresi Linear Berganda

Dalam penelitian ini metode analisis data yang digunakan adalah regresi linier berganda (multiple linier regression method) dengan pengolahan data melalui software SPSS (Statistical Package for Social Science). Dengan demikian model analisis dapat dinyatakan sebagai berikut :

$$
\begin{aligned}
& \mathrm{Y}=\alpha+\beta 1 \mathrm{X} 1+\beta 2 \mathrm{X} 2+\beta 3 \mathrm{X} 3+ \\
& \mathrm{e} . .
\end{aligned}
$$

Dimana :

$$
\begin{aligned}
& \mathrm{Y}=\text { Dividend Payout } \\
& \text { Ratio(DPR) } \\
& \alpha=\text { Intercept } / \text { Konstanta } \beta 1, \\
& \beta 2, \beta 3=\text { Koefisien regresi } \mathrm{i}= \\
& 1,2,3 \\
& \mathrm{e}=\text { Episilon atau variabel yang } \\
& \text { tidak diteliti } \\
& \mathrm{X} 1=\text { Current Ratio }(C R) \\
& \mathrm{X} 2=\text { Debt to Equity Ratio } \\
& (D E R)
\end{aligned}
$$

\section{X3 = Net Profit Margin (NPM)}

Parameter persamaan regresi linear berganda dapat ditaksir dengan menggunakan metode kuadrat terkecil biasa (ordinary least square method/OLS) karena dalam penelitian ini hanya terdapat satu variabel terikat (dependent variable) dengan lebih dari satu variabel bebas (independent variable).

Persamaan regresi linear berganda tersebut dapat menunjukkan nilai koefisien regresi atas setiap variabel bebas (independent variable), positif atau negatif. Koefisien regresi $b$ akan bernilai positif $(+)$ jika menunjukkan hubungan searah antara variabel bebas (independent variable) dengan variabel terikat (dependent variable). Artinya kenaikan variabel bebas akan mengakibatkan kenaikan variabel terikat dan sebaliknya, penurunan variabel bebas akan menurunkan variabel terikat. Koefisien regresi $b$ akan bernilai negatif (-) jika menunjukkan hubungan yang berlawanan arah antara variabel bebas dengan variabel terikat. Artinya kenaikan variabel bebas akan mengakibatkan penurunan variabel terikat dan sebaliknya, penurunan variabel bebas akan menaikkan variabel terikat.

Koefisien Korelasi

Analisi korelasi adalah metode statistika yang digunakan untuk menentukan kuatnya atau derajat 
hubungan linear antara dua variabel atau lebih. Semakin nyata hubungan linear (garis lurus), maka semakin kuat atau tinggi derajat hubungan garis lurus antara kedua variabel atau lebih. Ukuran untuk derajat hubungan garis lurus ini dinamakan koefisien korelasi.
Korelasi dilambangkan dengan $r$ dengan ketentuan nilai $r$ tidak lebih dari harga $(-1 \leq \mathrm{r} \leq 1)$. Apabila nilai $\mathrm{r}=-1$ artinya korelasi negatif sempurna, $r=0$ artinya tidak ada korelasi, dan $\mathrm{r}=1$ artinya korelasi sangat kuat.

\section{Tabel}

Interpretasi Koefisien Korelasi Nilai r

\begin{tabular}{|c|c|}
\hline Interval Koefisien & Tingkat Hubungan \\
\hline $0,800-1,000$ & Sangat Kuat \\
\hline $0,600-0,799$ & Kuat \\
\hline $0,400-0,599$ & Cukup Kuat \\
\hline $0,200-0,399$ & Lemah \\
\hline $0,000-0,199$ & Sangat Lemah \\
\hline
\end{tabular}

Koefisien Determinasi $\left(R^{2}\right)$

Koefisien determinasi $\left(\mathrm{R}^{2}\right)$ pada intinya mengukur seberapa jauh kemampuan model dalam menerangkan variasi variabel dependen. Nilai koefisien determinasi adalah antara nol sampai satu $\left(0<\mathrm{R}^{2}<1\right)$. Nilai $\mathrm{R}^{2}$ yang kecil berarti kemampuan variabelvariabel independen dalam menjelaskan variasi variabel dependen amat terbatas. Nilai yang mendekati satu berarti variabel-variabel memberikan hampir semua informasi yang dibutuhkan untuk memprediksi variasi variabel dependen.

Pengujian Hipotesis

Uji Pengaruh Serempak (Uji-F)

Langkah-langkah Uji F, adalah :

1. Menentukan hipotesis null dan hipotesis alternatif

a) H0: b1, b2, b3 = 0; secara serempak Current Ratio (CR), Debt to Equity Ratio (DER), Net Profit Margin (NPM) tidak mempunyai pengaruh yang signifikan terhadap Dividend Payout Ratio (DPR).

b) H1: b1, b2, b3 $\neq 0$; secara serempak Current Ratio (CR), Debt to Equity Ratio (DER), Net Profit Margin (NPM), mempunyai pengaruh yang signifikan terhadap Dividend Payout Ratio (DPR).

2. Menentukan nilai $F_{\text {tabel }}$ pada $\mathrm{dfl}=\mathrm{k}$ dan $\mathrm{df} 2=\mathrm{n}-\mathrm{k}-1$

3. Kriteria penerimaan sebagai berikut :

a) Jika $F_{\text {hitung }}>F_{\text {tabel }}$ berarti $\mathrm{H} 0$ ditolak Artinya variabel-variabel bebas (independent variable) tersebut secara simultan/serempak berpengaruh terhadap variabel terikat (dependent variable)

b) Jika $\mathrm{F}_{\text {hitung }} \leq \mathrm{F}_{\text {tabel }}$ berarti $\mathrm{H} 0$ diterima artinya variabel-variabel bebas (independent variable) tersebut secara simultan/serempak tidak berpengaruh terhadap variabel terikat (dependent variable)

2.1.1.1 Uji Pengaruh Parsial (Uji-t) Langkah-langkah Uji t, adalah :

1. Menentukan hipotesis null dan hipotesis alternative

a) H0: b1, b2, b3 =0; secara parsial Current Ratio (CR), Debt to Equity Ratio (DER), Net Profit Margin (NPM), tidak mempunyai pengaruh terhadap Dividend Payout Ratio (DPR). 
b) H2: b b1, b2, b3 $\neq 0$; secara parsial Current Ratio (CR), Debt to Equity Ratio (DER), Net Profit Margin (NPM), mempunyai pengaruh terhadap Dividend Payout Ratio (DPR).

2. Kriteria penerimaan sebagai berikut :

a) Terima $\mathrm{H} 0$ bila $-t_{\text {tabel }} \leq t_{\text {hitung }} \leq$ tabel b) Tolak H0 (terima H2) bila thitung $>$ $t_{\text {tabel }}$ atau $t_{\text {hitung }}<-t_{\text {tabel }}$

\section{HASIL PENELITIAN DAN} PEMBAHASAN

Berdasarkan kriteria yang telah dijelaskan sebelumnya tersebut, maka jumlah perusahaan yang menjadi sampel penelitian ini ada 15 perusahaan yaitu:

Tabel

Perusahaan yang terdaftar di Bursa Efek Indonesia (2010-2014)

\begin{tabular}{|c|c|c|c|}
\hline Sub Sektor Industri & No & Kode & Nama Perusahaan (Emiten) \\
\hline \multirow{3}{*}{$\begin{array}{ll}\text { INDUSTRI } & \text { DASAR } \\
\text { KIMIA (Basic } & \text { Industry } \\
\text { And Chemical) } & \end{array}$} & 1 & LION & PT Lion Metal Works Tbk \\
\hline & 2 & LMSH & PT Lionmesh Prima Tbk \\
\hline & 3 & SMGR & PT Semen Indonesia (Persero) Tbk \\
\hline \multirow{3}{*}{$\begin{array}{l}\text { ANEKA INDUSTRI } \\
\text { (Miscellaneous } \\
\text { Industry) }\end{array}$} & 4 & ASII & PT Astra International Tbk \\
\hline & 5 & AUTO & PT Astra Otoparts Tbk \\
\hline & 6 & SCCO & $\begin{array}{l}\text { PT Supreme Cable Manufacturing \& } \\
\text { Commerce Tbk }\end{array}$ \\
\hline \multirow{9}{*}{$\begin{array}{l}\text { INDUSTRI BARANG } \\
\text { KONSUMSI (Consumer } \\
\text { Goods Industry) }\end{array}$} & 7 & DLTA & PT Delta Djakarta Tbk \\
\hline & 8 & DVLA & PT Darya Varia Laboratorium Tbk \\
\hline & 9 & GGRM & PT Gudang Garam Tbk \\
\hline & 10 & HMSP & PT HM Sampoerna Tbk \\
\hline & 11 & INDF & PT Indofood Sukses Makmur Tbk \\
\hline & 12 & KLBF & PT Kalbe Farma Tbk \\
\hline & 13 & MYOR & PT Mayora Indah Tbk \\
\hline & 14 & TCID & PT Mandom Indonesia Tbk \\
\hline & 15 & UNVR & PT Unilever Indonesia Tbk \\
\hline
\end{tabular}

Sumber: idx.co.id

Hasil Penelitian

Deskripsi Variabel

Pada bagian ini akan disajikan statistika deskripsi dari variabel independen maupun variabel dependen. Variabel yang digunakan dalam penelitian ini adalah DPR, CR, DER, dan NPM. Data yang digunakan dalam penelitian ini untuk masing-masing variabel berjumlah 75 yang diperoleh dari 15 perusahaan dikalikan periode tahun pengamatan (5 tahun). Berikut ini adalah hasil statistik deskriptif dari data yang digunakan dalam penelitian ini: 
Tabel

Deskripsi Variabel

\begin{tabular}{|l|r|r|r|r|r|}
\hline & \multicolumn{1}{|c|}{ N } & \multicolumn{1}{c|}{ Mean } & Std. Deviation & Minimum & Maximum \\
\hline DPR & 75 & .4726 & .27656 & .03 & 1.21 \\
CR & 75 & 3.1126 & 2.37702 & .64 & 11.74 \\
DER & 75 & .5269 & .56691 & .01 & 2.10 \\
NPM & 75 & .1175 & .05684 & .03 & .26 \\
\hline
\end{tabular}

Deskripsi variabel diatas menunjukkan bahwa Divident Payout Ratio (DPR) minimum yaitu pada PT Lionmesh Prima, Tbk (LMSH) sebesar 0,03 kali sedangkan nilai maksimum yaitu PT Delta Djakarta (DLTA) sebesar 1,21 kali dan rata-rata DPR yaitu sebesar 0,4726 kali. Standar deviasi Divident Payout Ratio adalah sebesar 0,27656 kali.

Current Ratio terkecil (minimum) adalah 0,03 kali dan Current Ratio terbesar (maksimum) 11,74 kali, rataratanya 3,1126 kali dan dengan standar deviasi 2,37702 kali. Nilai Current Ratio terbesar dimiliki oleh PT Lion Metal Works Tbk (LION) pada tahun 2010 dan Nilai Current Ratio terkecil dimiliki oleh PT Unilever Indonesia Tbk (UNVR) pada tahun 2012.

Selama tahun 2010-2014 PT Kalbe Farma Tbk (KLBF) pada tahun 2010 memiliki nilai Debt to equity ratio (DER) terkecil (minimum) 0,1 kali dan DER terbesar (maksimum) sebesar 2,1 kali dimiliki oleh PT Unilever Indonesia Tbk (UNVR) pada tahun 2014. Rata-rata DER dari 15 perusahaan adalah 0,5269 kali dan standar deviasi 0,56691 kali.

Tingkat keuntungan dengan membandingkan laba bersih dengan penjualan (NPM) terkecil (minimum) dimiliki oleh PT Semen Indonesia Tbk (SMGR) pada tahun 2010 adalah 0,03 dan yang terbesar (maksimum) yaitu PT Lion Metal Works Tbk (LION) pada tahun 2012 sebesar 0,26 atau rata-ratanya 0,1175 dari 15 perusahaan dengan standar deviasi 0,05684 kali.

Uji Asumsi Klasik

Uji Normalitas

Uji normalitas akan dideteksi melalui analisa grafik (histogram dan Normal P-Plots) dan analisis statistik melalui uji statistik Non-Parametrik Kolmogorov-Smirnov (K-S).

1. Analisis grafik, yaitu dengan melihat grafik histogram dan grafik normal probability plot (Normal P-Plot) berikut ini: 


\section{Gambar \\ Hasil Uji Normalitas melalui Histogram Histogram}

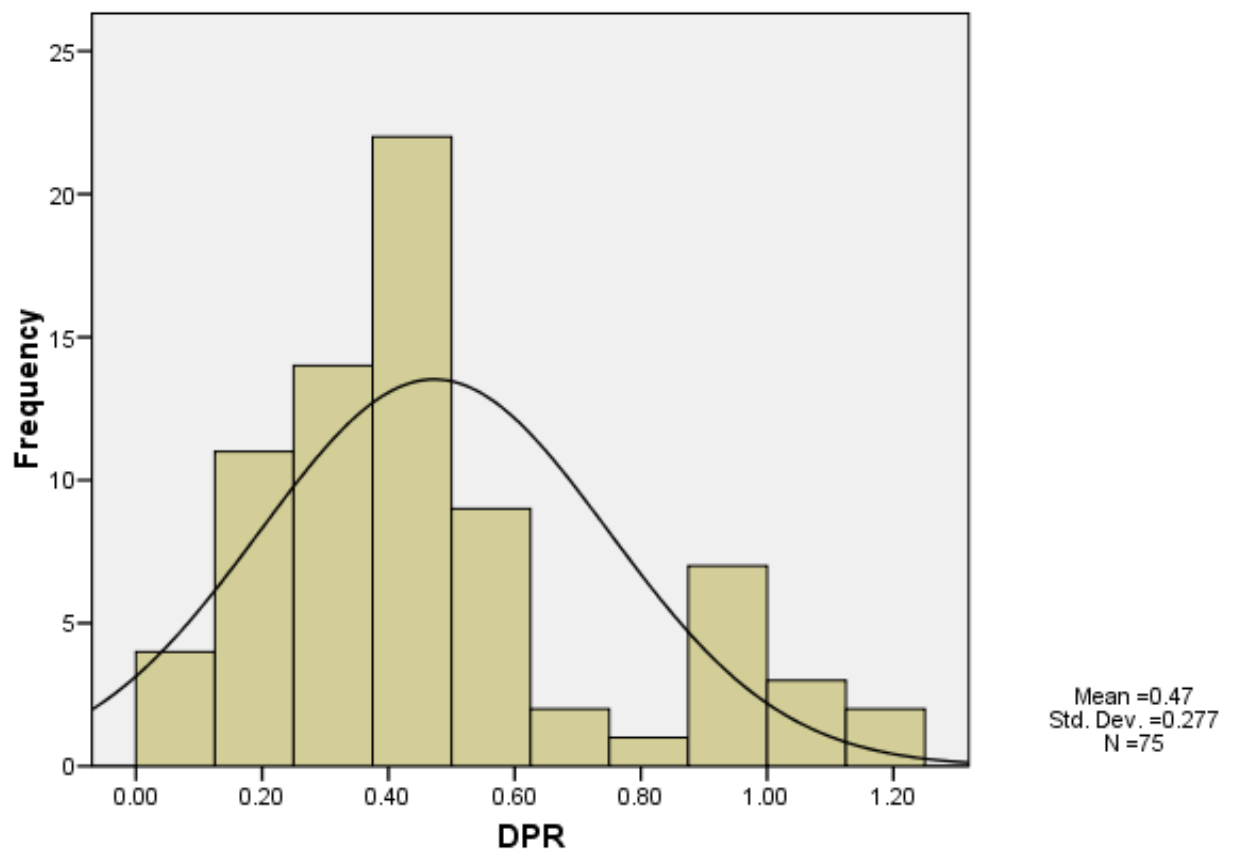

Normal P-P Plot of Regression Standardized Residual

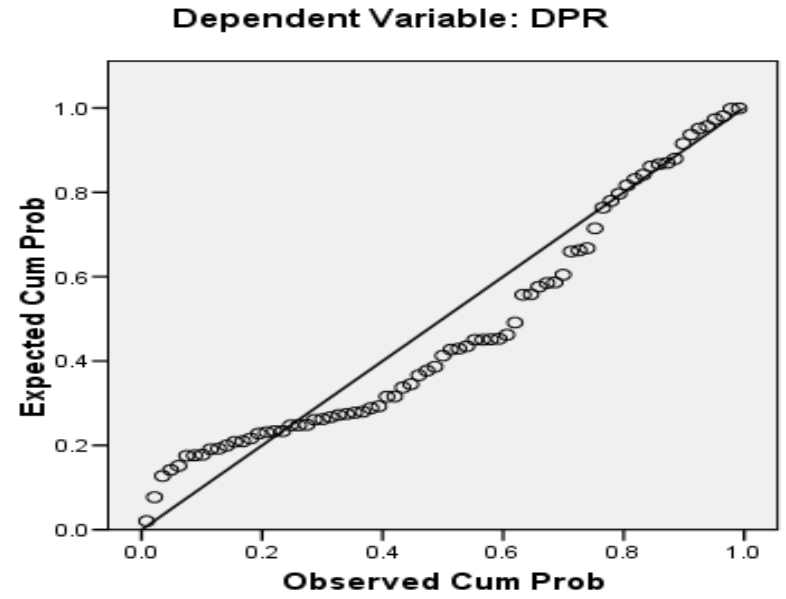

Dengan melihat tampilan grafik histogram, distribusi data membentuk lonceng (bell shaped). Tidak condong ke kiri ataupun ke kanan sehingga data dengan pola seperti ini memiliki distribusi normal. Tampilan grafik Normal P-Plot data menyebar sekitar garis diagonal dan mengikuti garis arah diagonal maka persyaratan normalitas sudah terpenuhi.

2. Analisis Statistik, hasil uji NonParametrik Kolmogorov-Smirnov (K-S) adalah sebagai berikut: 
Tabel

Hasil Uji Normalitas melalui Kolmogorov-Smirnov (K-S)

One-Sample Kolmogorov-Smirnow Test

\begin{tabular}{|ll|r|}
\hline & & $\begin{array}{r}\text { Unstandardiz } \\
\text { ed Residual }\end{array}$ \\
\hline Normal Parameters ${ }^{a, b} \quad$ Mean & 75 \\
& Std. Deviation & .0000000 \\
Most Extreme Differences & Absolute & .26019504 \\
& Positive & .150 \\
& Negative & .150 \\
Kolmogorov-Smirnov $Z$ & & -.106 \\
Asymp. Sig. (2-tailed) & & 1.300 \\
\end{tabular}

a. Test distribution is Normal.

b. Calculated from data.

Berdasarkan hasil diatas diketahui bahwa nilai Kolmogorov-Smirnov (K-S) sebesar 1.300 dengan Asymp. Sig (2tailed) sebesar 0,068 atau probabilitas diatas $0,05(0,068>0,05)$ maka dapat dinyatakan bahwa data berdistribusi normal.

\section{Uji Multikolineritas}

Menurut Ghozali (2005) pengujian ini dapat dilihat melalui nilai Tolerance dan Varians Inflation Factor (VIF), hasil uji multikolinearitas sebagai berikut:

Tabel

Hasil Uji Multikolinearitas

\begin{tabular}{|c|c|c|}
\hline \multirow[b]{2}{*}{ Model } & \multicolumn{2}{|c|}{ Collinearity Statistics } \\
\hline & Tolerance & VIF \\
\hline $1 \quad$ (Constant) & & \\
\hline $\mathrm{CR}$ & .883 & 1.133 \\
\hline a. Dependent Variable: & .806 & 1.241 \\
\hline NPM & .901 & 1.110 \\
\hline
\end{tabular}

Dari hasil analisis dan penyujran terhadap ketiga variable tersebut tidak terdapat gejala multikolinearitas. Hal ini dijelaskan oleh hasil perhitungan nilai Tolerance tidak ada variabel bebas yang memiliki nilai tolerance kurang dari 0,10 dan juga hasil perhitungan nilai Varians Inflation Factor (VIF) dari ketiga varraver tersevul, yaitu CR 1,133, DER memberikan nilai 1,241 , dan NPM memperoleh nilai 1,110 . Ketiga variabel tersebut memiliki nilai VIF $<10$, sehingga dapat disimpulkan bahwa tidak ada multikolinearitas antar variabel bebas (independent variable) dalam model regresi ini. 


\section{Uji Heteroskedastisitas}

Pengujian ini untuk melihat apakah dalam sebuah model regresi terjadi ketidaksamaan varian dari residual dalam rangkaian suatu pengamatan dan pengamatan lain.

Cara pengujian ini dilakukan dengan melihat grafik scatter plot, analisis data sebagai berikut:

\section{Gambar \\ Hasil Uji Heteroskedastisitas \\ Scatterplot}

1. Jika ada suatu pola tertentu seperti titik yang ada membentuk pola yang teratur, maka telah terjadi heteroskedastisitas

2. Jika tidak ada pola yang jelas, titik menyebar diatas dan dibawah angka 0 (nol), maka tidak terjadi heteroskedastisitas.

Dependent Variable: DPR

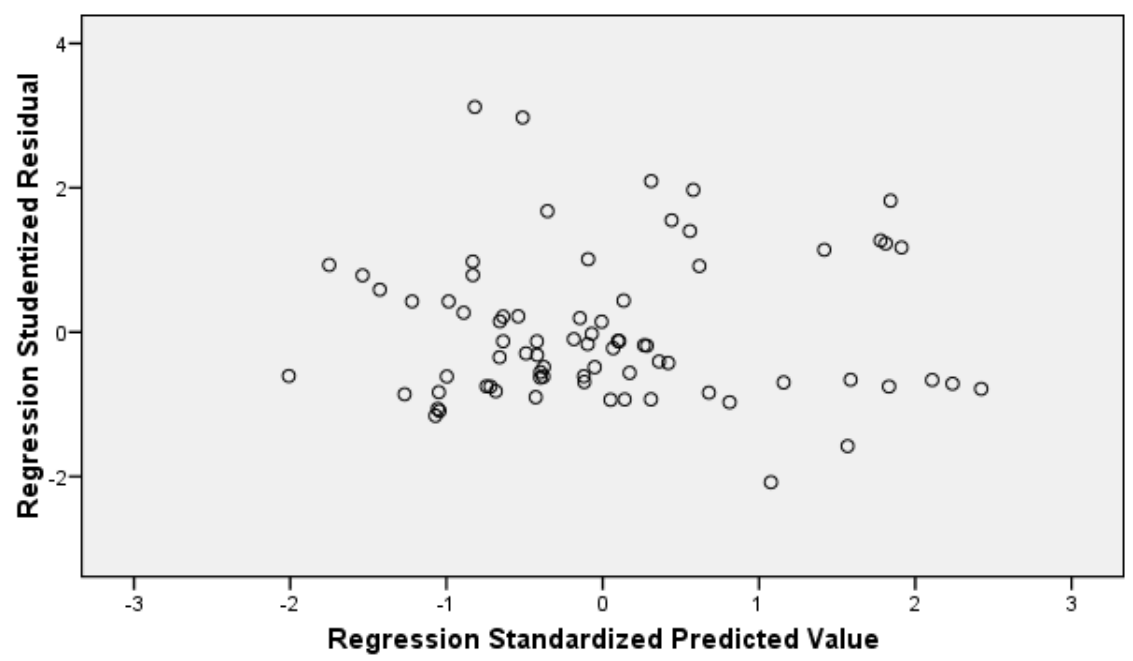

Sumber: Hasil Penelitian (data diolah)

Berdasarkan gambar 1.2 terlihat titiktitik menyebar secara acak baik diatas maupun dibawah angka 0 pada sumbu Y, dan juga terlihat titik-titik tersebut membentuk suatu pola tertentu. Dengan demikian dapat disimpulkan bahwa penelitian ini terbebas dari masalah heteroskedastisitas.

Uji Autokorelasi

Pengujian ini digunakan untuk menguji asumsi klasik regresi berkaitan dengan adanya autokorelasi. Pengujian ini ada tidaknya korelasi dalam persamaan ini digunakan uji Durbin Watson (DW-Test). Model regresi yang baik adalah model yang tidak mengandung autokorelasi. Autokorelasi dapat dideteksi bila nilai DW diluar du dan 4-du (Ghozali 2005). 
Tabel

Hasil Uji Autokorelasi (Durbin Watson)

Model Summaryb

\begin{tabular}{|l|r|r|r|r|r|}
\hline Model & $\mathrm{R}$ & R Square & $\begin{array}{c}\text { Adjusted } \\
\text { R Square }\end{array}$ & $\begin{array}{c}\text { Std. Error of } \\
\text { the Estimate }\end{array}$ & $\begin{array}{c}\text { Durbin- } \\
\text { Watson }\end{array}$ \\
\hline 1 & $.337^{a}$ & .114 & .076 & .26585 & .734 \\
\hline
\end{tabular}

a. Predictors: (Constant), NPM, CR, DER

b. Dependent Variable: DPR

Berdasarkan hasil regresi menunjukkan bahwa nilai $d_{\text {hitung }}$ sebesar 0,734 . Nilai

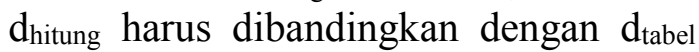
(d) yaitu $d_{L}$ dan $d_{U}$. dalam perhitungan ini diketahui bahwa $\mathrm{n}=75, \mathrm{k}=3$ dan $\alpha=0,05$ maka $d_{L}=1,5432$ dan $d_{U}=$ 1,7092. Ini menunjukkan bahwa nilai d berada pada daerah $0<0,734<1,5432$ sehingga $\mathrm{H}_{0}$ ditolak yang artinya tidak ada autokorelasi positif.

Analisis Regresi Linear Berganda

Analisis penelitian ini dilakukan terhadap hasil perhitungan dan pengujian data sekunder (historis) atas laporan keuangan dari 15 sampel perusahaan manufaktur selama 5 tahun yang tercatat di Bursa Efek Indonesia (BEI) dari tahun 2010-2014.

Pengujian ini dilakukan dengan menggunakan model regresi linear berganda untuk menguji ada tidaknya pengaruh variabel independen terhadap variabel dependennya (DPR) baik secara simultan maupun secara parsial.

Adapun hasil dari pengolahan data adalah sebagai berikut:

Tabel

\section{Hasil Uji Regresi Linear Berganda}

Coefficients $^{a}$

\begin{tabular}{|c|c|c|c|c|c|c|c|c|}
\hline \multirow{2}{*}{\multicolumn{2}{|c|}{ Model }} & \multicolumn{2}{|c|}{$\begin{array}{l}\text { Unstandardized } \\
\text { Coefficients }\end{array}$} & \multirow{2}{*}{$\begin{array}{c}\begin{array}{c}\text { Standardized } \\
\text { Coefficients }\end{array} \\
\text { Beta }\end{array}$} & \multirow[b]{2}{*}{$t$} & \multirow[b]{2}{*}{ Sig. } & \multicolumn{2}{|c|}{ Collinearity Statistics } \\
\hline & & $\mathrm{B}$ & Std. Error & & & & Tolerance & VIF \\
\hline \multirow[t]{4}{*}{1} & (Constant) & .297 & .103 & & 2.895 & .005 & & \\
\hline & $\mathrm{CR}$ & -.012 & .014 & -.106 & -.895 & .374 & .883 & 1.133 \\
\hline & DER & .034 & .061 & .069 & .557 & .580 & .806 & 1.241 \\
\hline & NPM & 1.658 & .574 & .340 & 2.888 & .005 & .901 & 1.110 \\
\hline
\end{tabular}

a. Dependent Variable: DPR

persamaan regresi linear berganda yaitu:

$\mathrm{DPR}=0,297-0,012 \mathrm{X} 1+0,034 \mathrm{X} 2$

$+1,658$ X3

$\mathrm{F}=3,033 \quad \mathrm{Sig}=0,035$

$\mathrm{R}^{2}=0,076$

Berdasarkan persamaan regresi linear berganda tersebut dapat dijelaskan bahwa konstanta (a) sebesar 0,297 yang berarti besarnya DPR adalah sebesar 0,297 tanpa adanya Current Ratio (CR),

Debt to Equity Ratio (DER), dan Net Profit Margin (NPM).

1. Koefisien regresi Current Ratio (CR) adalah sebesar -0,012 yang berarti bahwa setiap perubahan CR sebesar satu satuan akan menurunkan DPR sebesar 1,2\% dengan asumsi variabel yang lain konstan. 
2. Koefisien regresi Debt to Equity Ratio (DER) adalah sebesar 0,034 yang berarti bahwa setiap perubahan DER sebesar satu satuan akan meningkatkan DPR sebesar 3,4\% dengan asumsi variabel yang lain konstan.
3. Koefisien regresi Net Profit Margin (NPM) adalah sebesar 1,658 yang berarti bahwa setiap perubahan NPM sebesar satu satuan akan meningkatkan DPR sebesar $165,8 \%$ dengan asumsi variabel yang lain konstan.

Koefisien Korelasi

Tabel

Hasil Uji Korelasi

Model Summaryb

\begin{tabular}{|l|r|r|r|r|}
\hline Model & R & R Gquare & $\begin{array}{c}\text { Adjusted } \\
\text { R Square }\end{array}$ & $\begin{array}{r}\text { Std. Error of } \\
\text { the Estimate }\end{array}$ \\
\hline 1 & $.337^{3}$ & .114 & .076 & .26585 \\
\hline
\end{tabular}

a. Fredictors: (Constant), NFl, CR, DEF

b. Dependent Variable: DPR

Sumber: Hasil Penelitian (data diolah)

Berdasarkan tabel $\quad 1.8 \quad$ (DER), dan Net Profit Margin (NPM)

menunjukkan bahwa nilai koefisien berhubungan lemah terhadap Dividend

korelasi (R) sebesar 0.337. Artinya Payout Ratio (DPR).

Current Ratio (CR), Debt to Equity Ratio $\quad$ Koefisien Determinasi $\left(R^{2}\right)$

Tabel

Hasil Uji Determinasi

Model Summaryb

\begin{tabular}{|l|r|r|r|r|}
\hline Model & R & R Square & $\begin{array}{c}\text { Adjusted } \\
\text { R Square }\end{array}$ & $\begin{array}{r}\text { Std. Error of } \\
\text { the Estimate }\end{array}$ \\
\hline 1 & $.337^{a}$ & .114 & .076 & .26585 \\
\hline
\end{tabular}

a. Predictors: (Constant), NPM, CR, DER

b. Dependent Variable: DPR

Sumber: Hasil Penelitian (data diolah)

Berdasarkan tabel 1.9

$7,6 \%$ sedangkan selebihnya $92,4 \%$ menunjukkan bahwa nilai koefisien determinasi $\left(\mathrm{R}^{2}\right)$ sebesar 0.076 atau $7,6 \%$. Artinya independen variabel Current Ratio (CR), Debt to Equity Ratio (DER), dan Net Profit Margin (NPM) mampu menjelaskan dependen variabel Dividend Payout Ratio (DPR) sebesar dijelaskan oleh faktor-faktor lain yang tidak digunakan dalam penelitian ini.

Faktor-faktor tersebut kemungkinan antara lain tingkat pertumbuhan perusahaan (growth), risiko pasar, ukuran perusahaan, dan kondisi makro lainnya seperti jatuhnya 
nilai tukar rupiah terhadap dollar Amerika, pajak penghasilan, tingkat bunga, dan lain-lain (Rini Dwiyani Hadiwidjaja, 2008).

\section{Pengujian Hipotesis}

Pada penelitian ini dilakukan pengujian hipotesis terhadap 3 (tiga) variabel bebas (independent varable) apakah mempunyai pengaruh terhadap variabel terikatnya (DPR) baik secara serempak maupun secara parsial.

Uji Pengaruh Serempak (Uji-F)

Uji ini dilakukan untuk mengetahui apakah ada pengaruh yang signifikan secara serempak antara variabel bebas dengan variabel terikatnya.

\section{Hasil Uji Pengaruh Serempak (Uji-F) ANOVA ${ }^{b}$}

\begin{tabular}{|ll|r|r|r|r|l|}
\hline Model & & $\begin{array}{c}\text { Sum of } \\
\text { Squares }\end{array}$ & df & Mean Square & F & Sig. \\
\hline 1 & Regression & .643 & 3 & .214 & 3.033 & $.035^{3}$ \\
& Residual & 5.018 & 71 & .071 & & \\
& Total & 5.661 & 74 & & & \\
\hline
\end{tabular}

a. Predictors: (Constant), NPM, CR, DER

b. Dependent Variable: DPR

Sumber: Hasil Penelitian (data diolah)

Hasil pengolahan data terlihat bahwa variabel independen (CR, DER, NPM) memiliki nilai $F$ hitung sebesar 3,033 dengan tingkat signifikansi sebesar 0,035 yang lebih kecil dari tingkat signifikansi $0,05 \quad(5 \%)$. Maka dengan demikian dapat disimpulkan hasil analisis dalam penelitian ini menunjukkan bahwa secara bersama- sama dan signifikan variabel independen (CR, DER, NPM) memberikan pengaruh terhadap variabel dependen (DPR) dan hipotesis diterima.

Uji Pengaruh Parsial (Uji-T)

Uji ini dilakukan untuk mengetahui apakah ada pengaruh yang signifikan secara parsial antara variabel bebas:

\section{Tabel}

Hasil Uji Pengaruh Parsial (Uji-t)

Coefficients $^{\Xi}$

\begin{tabular}{|c|c|c|c|c|c|c|c|c|}
\hline \multirow[b]{2}{*}{ Made } & & \multicolumn{2}{|c|}{ Unstandardized Coefficients } & \multirow{2}{*}{$\begin{array}{c}\begin{array}{c}\text { Standardized } \\
\text { Coefficients }\end{array} \\
\text { Beta } \\
\end{array}$} & \multirow[b]{2}{*}{$t$} & \multirow[b]{2}{*}{ Siq. } & \multicolumn{2}{|c|}{$95.0 \%$ Confidence Interval for B } \\
\hline & & B & Std. Error & & & & Lower Bound & Upper Bound \\
\hline \multirow[t]{4}{*}{1} & (Constant) & .296 & .103 & & 2.878 & .005 & .091 & .500 \\
\hline & Current Ratio & -.012 & .014 & -.103 & -864 & .391 & -.040 & .016 \\
\hline & Debt to Equity Ratio & .035 & .061 & .072 & .577 & .566 & -.086 & .156 \\
\hline & Net Profit Margin & 1.665 & .573 & .342 & 2.907 & .005 & .523 & 2.807 \\
\hline
\end{tabular}

a. Dependent Variable: Divident Payout Ratio

Sumber: Hasil Penelitian (data diolah)

Pengaruh Current Ratio Terhadap DPR

Hipotesis pertama menyebutkan bahwa CR berpengaruh positif terhadap DPR. Berdasarkan hasil perhitungan data menggunakan program SPSS diperoleh hasil bahwa nilai signifikansi sebesar
0,391. Ini berarti HO diterima, artinya CR tidak berpengaruh positif dan signifikan terhadap DPR karena nilai signifikansi lebih besar dari 0,05 . 
Pengaruh Debt to Equity Ratio Terhadap DPR

Faktor DER sebagai variabel bebas mempunyai pengaruh yang negatif dan tidak signifikan secara parsial (Tabel 1.10) terhadap DPR, hal ini ditunjukkan dari nilai thitung sebesar 0,577 dan tingkat signifikansi 0,566 lebih besar dari alpha 0,05 . Sehingga variabel DER berpengaruh positif namun tidak signifikan secara parsial terhadap DPR.

Pernyataan ini didukung oleh Suhartono (2004) yang menyatakan bahwa interaksi antara kebijakan hutang dan kebijakan dividen dapat dihubungkan dengan asmetris informasi, yakni informasi yang mencakup informasi tentang prospek perusahaan dan penggunaan keuntungan, artinya ada hubungan interdependensi antara kebijakan hutang dan kebijakan dividen. Hal ini seperti teori pecking order dari Myers (1984), dimana perusahaan lebih memilih untuk menggunakan pembiayaan internal dibandingkan eksternal, dan akan mengadaptasi target rasio pembayaran dividen mereka ke dalam peluang nvestasi. Dalam teori pecking order juga dinyatatakan bahwa tidak ada target struktur modal optimal (debt to equity ratio). Sedangkan Gitosudarmo (2002) berpendapat bahwa terjadi hubungan yang berlawanan (negatif) antara DER terhadap DPR, artinya semakin tinggi rasio ini maka akan semakin kecil pembayaran dividen.

Hasil penelitian ini juga sejalan dengan penelitian yang dilakukan Fitriyani (2002) yang menyatakan bahwa variabel Debt to Equity Ratio (DER) berpengaruh negatif namun tidak signifikan terhadap DPR.

Pengaruh Net Profit Margin Terhadap DPR

Variabel NPM sebagai variabel bebas mempunyai pengaruh yang positif dan signifikan secara parsial (tabel 4.9) terhadap DPR. Hal ini dapat dilihat pada tabel 1.10 dari tabel tersebut diketahui bahwa NPM memiliki thitung sebesar 2,907 dengan tingkat signifikasi 0,005 dan nilai trabel sebesar 1,993, dimana thitung $(2,907)>t_{\text {tabel }}(1,993)$ sehingga Ho ditolak, artinya NPM berpengaruh positif secara parsial dan signifikan terhadap DPR. Pernyataan ini sejalan dengan pernyataan Suhartono (2004) bahwa Earning Volatility berkaitan dengan rasio dividen. Apabila tingkat keuntungan perusahaan semakin stabil maka perusahaan dapat memprediksi keuntungan-keuntungan dimasa yang akan datang dengan ketepatan yang lebih tinggi. Kesimpulan penelitian ini tidak sejalan dengan penelitian yang dilakukan Rini (2007) dan Nasrul (2004) yang menyatakan bahwa variabel NPM tidak berpengaruh terhadap DPR.

\section{Kesimpulan}

Berdasarkan hasil analisa data dan pembahasan pada bab sebelumnya, ada beberapa hal yang dapat disimpulkan yaitu:

1. Rasio Current Ratio (CR), tidak berpengaruh positif dan signifikan terhadap DPR (dengan nilai signifikan 0,391 dan nilai t hitung $0,864)$

2. Rasio Debt to Equity Ratio (DER), berpengaruh positif namun tidak signifikan secara parsial terhadap DPR. (dengan nilai signifikan 0,566 dan nilai t hitung 0,577 )

3. Rasio Net Profit Margin (NPM) NPM berpengaruh positif secara parsial dan signifikan terhadap DPR. (dengan nilai signifikan 0,005 dan nilai $\mathrm{t}$ hitung 2,907).

4. Koefisien determinasi yang menyatakan bahwa Current Ratio (CR), Debt to Equity Ratio (DER), 
dan Net Profit Margin (NPM) mampu menjelaskan DPR sebesar 7,6\% sedangkan sisanya 92,4\% dijelaskan oleh faktor-faktor yang lainnya.

5. Koefisien Korelasi menunjukkan bahwa nilai koefisien korelasi (R) sebesar 0.337 atau 33,7\%. Artinya Current Ratio (CR), Debt to Equity Ratio (DER), dan Net Profit Margin (NPM) berhubungan lemah terhadap Dividend Payout Ratio (DPR).

\section{Saran}

Sebagai implikasi dari hasil penelitian ini, peneliti memberikan beberapa saran sebagai berikut:

1. Bagi para emiten dan manajemen perusahaan sebaiknya mempertimbangkan posisi Net Profit Margin (NPM) dalam menetapkan rasio pembayaran dividen (dividend payout ratio), serta meningkatkan posisi profitabilitas dengan cara meningkatkan laba bersih perusahaan.

2. Dari hasil penelitian ditemukan juga bahwa faktor-faktor yang diteliti hanya memberikan pengaruh yang kecil terhadap Dividend Payout Ratio (DPR) yaitu sebesar 33,7\%, oleh karena itu bagi para pemegang saham dan manejemen perusahaan sebaiknya mempertimbangkan juga faktor lain diluar faktor yang diteliti sebagai masukan dalam pengambilan keputusan investasi maupun penetapan kebijakan dividen.

3. Bagi para akademis yang tertarik untuk melakukan penelitian lebih lanjut mengenai Dividend Payout Ratio (DPR), sebaiknya menggunakan objek penelitian, periode penelitian, alat analisis dan faktor-faktor yang berbeda dengan penelitian ini, seperti pertumbuhan perusahaan (growth), risiko pasar, nilai tukar rupiah terhadap dollar, dan tingkat bunga.

\section{DAFTAR PUSTAKA}

Arikunto, Suharsimi. 2002. Prosedur Penelitian. Edisi Revisi V. Cetakan Kedua belas. PT. Rineka Cipta. Jakarta.

Atmaja, Lukas Setia. 2003. Manajemen Keuangan. Edisi Revisi. Penerbit Andi. Yogyakarta.

Brealey, Richard A. and Stewart C. Myers. 2004. Principles of Corporate Finance. 7th Edition. McGraw-Hill Companies, Inc.

Brigham, Eugene F. and Joel F. Houston. 2001. Manajemen Keuangan. Dialih bahasakan oleh Dodo Suharto dan Herman Wibowo. Buku Satu. Edisi Kedelapan. Erlangga. Jakarta.

Ghozali, Imam. 2005. Aplikasi Analisis Multivariate dengan Program SPSS. Universitas Diponegoro. Semarang.

Gitosudarmo, Indriyo dan $H$. Basri. $2002 . \quad$ Manajemen Keuangan. Edisi Keempat. Cetakan Pertama. BPFE, Yogyakarta.

Harahap, Sofyan Syafri. 2004. Analisis Kritis atas Laporan Keuangan. Edisi Pertama. Cetakan Keempat. PT Raja Grafindo Persada, Jakarta.

Helfert, Erich. A. 1997. Teknik Analisis Keuangan: Petunjuk Praktis untuk Mengelola dan Mengukur Kinerja Perusahaan. Dialih bahasakan oleh Herman Wibowo. Edisi Kedelapan. Erlangga. Jakarta.

Husnan, Suad. 1998. Manajemen Keuangan Keputusan Investasi dan Pembelanjaan. Edisi Kedua. BPFE. Yogyakarta.

Husnan, Suad dan Enny Pudjiastuti. 
1998 Dasar-dasar Manajemen Keuangan. Edisi Kedua. UPP YKPN. Yogyakarta.

Keown, Arthur J., David F. Scott, Jhon.D. Martin, and William J. Petty. 1999. Basic Financial Management. $8^{\text {th }}$ Edition. Prentice Hall International,Inc. NewJersey.

Kieso, Donald E. and Jerry J. Wrygrandt. $1995 . \quad$ Intermediate Accounting. Dialihbahasakan oleh Herman Wibowo. $7^{\text {th }}$ Edition. John Willey and Sons, Inc.

Kuswadi. 2006. Memahami Rasio-Rasio Keuangan Bagi Orang Awam. PT Gramedia Pustaka Utama. Jakarta.

Martono dan Agus Harjito. 2001. Manajemen Keuangan. Edisi Pertama. Cetakan Pertama. Ekonisia.

FE UII. Yogyakarta.

Nasir, Mohammad. 1999. Metode Penelitian. Cetakan Keempat. Ghalia Indonesia. Jakarta.

Rini, Dwiyani Hadiwidjadja, 2007. Analisis Faktor-Faktor Yang Mempengaruhi Dividend Payout Ratio Pada Perusahaan Manufaktur Yang Terdaftar Di BEI

Riyanto, Bambang. 1997. Dasar-dasar Pembelanjaan Perusahaan. Edisi Keempat. UPP YKPN. Yogyakarta.

Ross, Stephen A.Westerfield, and Jaffe. 2002. Corporate Finance. $6^{\text {th }}$ Edition. Revised Printing. McGraw-Hill. Boston.

Sawir, Agnes. 2005. Analisis Kinerja Keuangan dan Perencanaan Keuangan Perusahaan.
Cetakan Kelima. PT Gramedia Pustaka Utama. Jakarta.

Santoso, Singgih. 2005. Menguasai Statistik di Era Informasi dengan SPSS 12. PT Elex Media Komputindo. Jakarta.

Sartono, Agus. 2000. Ringkasan Teori Manajemen Keuangan. Edisi Ketiga. Cetakan Kedua. BPFE. Yogyakarta.

Sinuraya, Murthada. 1999. Teori Manaje men Keuangan. Edisi Revisi. FEUI. Jakarta.

Sundjaja, Ridwan dan Inge Barlian. 2002. Manajemen Keuangan 2. PT Prenhallindo. Jakarta.

Sutrisno, Ekonisisa, 2000. Manajemen Keuangan: Teori, Konsep, dan Aplikasi, Yogyakarta

Weston, Fred J, Scott Besley, Eugene Brigham. 1996. Essential of Managerial Finance, $11^{\text {th }}$ Edition. The Dryden Press. Harcourt Brace College Publishers.

Weston, Fred J. and Brigham. 1994. Dasar-dasar Manajemen Keuangan. Dialih bahasakan oleh Alfonsus Sirait. Jilid Pertama. Edisi Kesembilan. Erlangga. Jakarta.

Weston, Fred J. and Thomas E. Copeland. 1993. Dasar-dasar Manajemen Keuangan. dialih bahasakan oleh Jaka Wasana dan Kirbrandoko. Jilid Pertama. Edisi Kedelapan (Revisi). Alfabeta. Bandung.

Tesis :

Fitriyani, Lita Yulita. 2002. Analisis Variabel-variabel yang mempengaruhi Dividend Payout Ratio pada Industri 
Manufaktur di Bursa Efek Jakarta. Tesis Program Pendidikan Magister Universitas Padjajaran. Bandung. (tidak dipublikasikan).

Hariani, Emi. 2005. Analisis Variabelvariabel yang Mempengaruhi Dividend Payout Ratio pada Perusahaan Publik di Indonesia. Tesis Program Pascasarjana USU. Medan. (tidak dipublikasikan).

Nasrul, Idiansyah Harahap. 2004. Analisis Faktor-faktor yang Mempengaruhi Dividend Payout Ratio pada Perusahaan Manufaktur GoPublic di Bursa Efek Jakarta. Tesis Program Pascasarjana USU. Medan. (tidak dipublikasikan).

Nasution, Hasanul Aswadi. 2004. Faktor-faktor yang Mempengaruhi Dividend Payout Ratio pada Perusahaan Publik di Indonesia, Tesis Program Pascasarjana USU. Medan.

(tidak dipublikasikan)

\section{Disertasi :}

Sugihen,

Syafruddin Ginting. 2003. Pe ngaruh Struktur Modal Terha dap Produktivitas Aktiva dan Kinerja Keuangan Serta Nilai Perusahaan Industri Manufaktur Di Indonesia. Disertasi Program Pascasarjana Universitas Airlangga. Surabaya. (tidak dipublikasikan).

\section{Jurnal :}

Damayanti, Susana dan Fatchan Achyani. 2006. Analisis Pengaruh Investasi, Liquiditas, Profitabilitas, Pertumbuhan Perusahaan dan Ukuran Perusahaan Terhadap Kebijakan Dividen Payout Ratio (Studi Empiris pada Perusahaan Manufaktur yang Terdaftar di BEJ). Jurnal Akuntansi dan Keuangan Volume 5. No. 1. April 2006. Universitas Muhammadyah Surakarta.

Halim, Johan. 2005. Pengaruh Likuiditas, Leverage dan Dividen Terhadap Price Earning Ratios pada Industri Manufaktur Di Bursa Efek Jakarta. Balance. Maret. Fakultas Ekonomi Universitas Katolik Indonesia Atmajaya.

Marlina, Lisa dan Clara Danica. 2009. Analisis pengaruh cash position, debt to equity ratio, dan return on asset terhadap dividend payout raio. Jurnal manajemen bisnis. Vol. 2, No. 1, Ha. 1-6.

Myers, S.C. \& Maljuf,N.s (1984). "Corporate Financing and Investment Decision When Firms Have Information That Investors Do Not Have, "Journal of Financial Economics. pp. 187-221.

McManus, Gwilyn and S. H Thomas. 2002. A Robust Estimation of The Relation between Stock Returns, Size, Dividend Yield and Payout Ratio. The EFMA Conference. School of 
Management. University of Southampton

Nursalam. 2008. Konsep dan Penerapan Metodologi Penelitian Ilmu Keperawatan, Edisi 2 Pedoman Skripsi, Tesis dan Instrumen Penelitian Keperawatan. Jakarta; Salemba Medika

Suhartono. 2004. Pengujian Terhadap Keterkaitan Antara Kebijakan Dividend an Kebijakan Hutang Secara Simultan Pada Perusahaan Manufaktur Yang
Terdaftar di Bursa Efek Jakarta. Ventura. Vol. 7 No.1, April

Uyara, Ali Sani dan Askam Tuasikal. 2003. Moderasi Aliran Kas Bebas Terhadap Hubungan Rasio Pembayaran Dividend an Pen geluaran Modal Earnings Response Coefficients. Jurnal Riset Akuntansi Indonesia. Vol 6 No. 2. Mei. 